\title{
Defining the Excavated Layer's Height for Coal Extraction by Backhoes
}

\author{
Oleg Litvin \\ Mining Institute \\ T.F. Gorbachev Kuzbass State \\ Technical University \\ Kemerovo, Russian Federation \\ litvinoi@kuzstu.ru \\ Sergey Markov \\ Mining Institute \\ T.F. Gorbachev Kuzbass State \\ Technical University \\ Kemerovo, Russian Federation \\ markovso@kuzstu.ru
}

\author{
Maxim Tyulenev \\ Mining Institute \\ T.F. Gorbachev Kuzbass State \\ Technical University \\ Kemerovo, Russian Federation \\ tma.geolog@kuzstu.ru
}

\author{
Sergey Zhironkin \\ Mining Institute \\ T.F. Gorbachev Kuzbass State \\ Technical University \\ Kemerovo, Russian Federation \\ zhironkint@inbox.ru
}

\begin{abstract}
Currently, large machine building companies produce hydraulic excavators serially with a wide range of operating parameters (bucket capacity, digging radius, digging depth and height). Hydraulic excavators have found wide application in quarries all over the world (USA, France, England, Japan, Australia, Russian Federation etc.). A sufficiently wide range of backhoe capabilities for the formation of various forms of surface workings and bench slopes allows them to work without leaving various prisms of coal losses in the coal seam's bottom, at the optimum height of the excavated layer. The most efficient way is to work off the bench by hydraulic backhoe by downward digging and bottom loading. The depth of digging (the height of the face) is approximately equal to the height of the body of a dump truck. The minimum value of the excavation cycle is achieved when the dump truck is positioned at an angle of $35-60^{\circ}$ to the axis of the excavator. To reduce the time for installing a dump truck for loading, an end-to-end truck approach scheme is recommended, but the duration of the excavation cycle is increased as a result of increasing the angle of the excavator during loading. The research shows that: (1) at the excavated layer's height of $5.0 \mathrm{~m}$, additional coal losses due to nonscooping is not formed only for seam's angle of 50 or more, except when using hydraulic backhoes with large operating parameters; (2) for excavated layer's height of $4.0 \mathrm{~m}$, the minimal coal losses will be achieved for dip angle of at least 40 degrees, and for long-boom excavators - not less than $30^{\circ}$; (3) the excavated layer's height of $3.0 \mathrm{~m}$ makes it possible to virtually eliminate coal losses, except for excavators with a short boom.
\end{abstract}

Keywords-open pit mining, hydraulic backhoes, excavated layer, coal losses, backhoe productivity

\section{INTRODUCTION}

Coal mining industry is one of the most fast developing industries due to expanding of open pit mining [1-3]. Economic advantages of open pit mining [4-6] inspire rapid development of various excavation equipment [7-9].

There are rope and hydraulic backhoe getting used at surface mining. Rope backhoes are produced mainly with a rope system for moving work equipment. The bucket of the excavator is fixed by pulling on the handle, which is articulated to the upper end of the boom. The handle turns when moving the pulling or lifting rope (with the simultaneous weakening of the other). The angle of inclination of the boom of the backhoe, which is fixed to the platform, is continuously changed during operation. When the boom is lowered, the bucket teeth are impacted by the weight of the working equipment. Digging of the rock is carried out by pulling the bucket to the excavator with a pulling rope at the disinhibited lifting rope. After the bucket with the rock will be pulled up to the boom, it, together with the handle and the boom, is lifted from the face, and then, together with the platform, it is turned to the place of unloading. Unload the rock (in the dump, vehicle, crushing unit, bunker at the level of installation of the excavator or below) from the bucket is made by turning it together with the handle relative to the boom. After that, the working equipment is moved to the starting position for the subsequent digging cycle [10-13].

At open mining, the rope backhoes were gradually replaced by hydraulic backhoes with the best kinematic and weight characteristics.

The hydraulic backhoe includes basically the same main elements as the rope backhoe, with the exception of an additional pillar supporting the hoisting rope. In addition, the lifting of the boom, the rotation of the handle and the bucket are carried out due to the forces created by the hydraulic cylinders. Under the influence of these hydraulic cylinders, as well as the weight of the working equipment, the bucket is introduced into the rock. The hydraulic cylinder can change the dip angle of the bucket in relation to the handle. This improves the degree of its loading, increases the discharge speed and is one of the main advantages of hydraulic backhoe before mechanical ones. Unloading the bucket with a hydraulic backhoe, unlike the mechanical one, is accomplished by turning the bucket relative to the handle. From the 1970's and 80's, backhoes were more often used at open pit mining for excavating coal and rock benches by bottom scooping. The productivity of the excavator with backhoe equipment is usually 10-15\% lower than for shovel. 
Since 1980th, hydraulic excavators of the quarry type have been widely used in the world open pit mining, after beginning their serially production by the largest world machine building companies (Terex, Komatsu, Volvo, Caterpillar, Hitachi, Liebherr).

The first experimental use of Russian hydraulic backhoes was carried out in 1980-1985 on "Baidaevsky" and "Krasnogorsky" open pits (Kemerovo region) for working on inclined and flat coal seams. The results confirmed the effectiveness of hydraulic backhoes. However, because quarry hydraulic backhoes were not serially manufactured by Russian producers, this experience was left single.

Already by 1970 , about a dozen models of powerful quarry hydraulic backhoes with a bucket capacity from 5 to 15 m3 (RH-75, RH-300, H-III, H-241, etc.) were created.

The variety of use of hydraulic excavators in coal quarries is due to various mining and geological conditions of coal seams bedding. Hydraulic backhoes have an additional extent of bucket rotation and can work with upward and downward scooping and loading of rock mass at the level of standing of the excavator, as well as above and below its installation [14]. Due to this, the use of hydraulic backhoes in the coal-bearing zone allows the following:

- producing a high-quality cleaning of the roof of the coal seam before excavation;

- working with the downward scooping and carry out lifting the rock mass in the bucket with loading it into transport vessels at or above the level of the excavator's position, which leads to a reduction in the transportation distance;

- conducting layered (by horizontal layers) coal seams and rock inter-layers excavation;

- carry out clean selective excavation of coal packs and rock layers from a complex formation;

- producing a new horizon with simultaneous development of the coal seam;

- developind flooded faces, while motor transport works under favorable conditions, since loading of rock mass into motor vehicles is carried out on the upper landing area;

- carrying out lower loading of rock mass into dump trucks, thus reducing the operational time of the excavation cycle and, therefore, increasing productivity.

Hydraulic excavators work on the quarries of many countries (Sweden, Canada, USA, England, Germany, and France). The main parameters of technological schemes: the height of the layer being worked varies from 3 to $8 \mathrm{~m}$, the width of the penetration is from 6 to $20 \mathrm{~m}$.

\section{THEORETICAL PROVISIONS FOR EXCAVATED LAYER'S HEIGHT DEFINING}

In most cases, dump trucks are backed to the left side of the excavator, as the excavator operator and dump truck driver can see each other. The angle of rotation of the excavator during loading varies from 60 to $135^{\circ}$. To reduce the time for the exchange of dump trucks, they can be reversed to the left and to the right. In well-divided rocks, the excavator can load the layers from top to bottom, which reduces the time due to the reduction of the bucket lift time.
The bucket can be introduced at any height parallel to the bottom of the bench, which is important for the selective excavation of coal seams (Fig. 1).

For the conditions of Kuzbass (The largest coal basin in Russian Federation, located in Kemerovo region), hydraulic backhoes can be used for working off stripping benches for

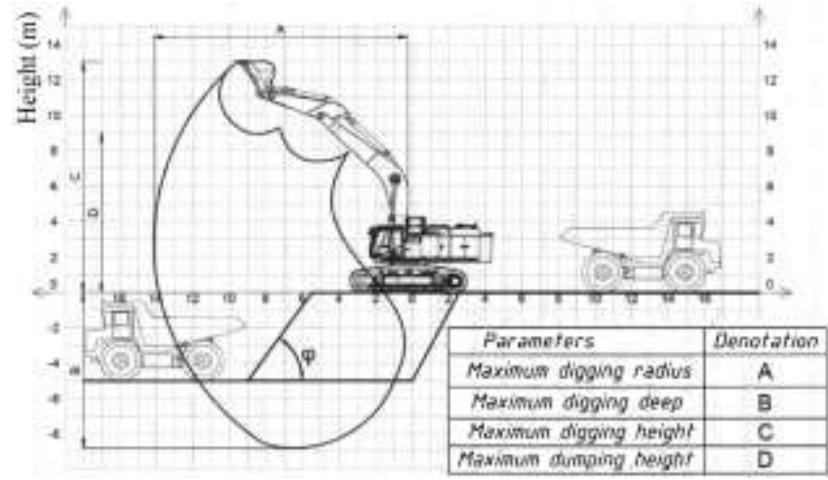

Fig. 1. Scheme of technological capabilities and basic parameters of the working equipment of the hydraulic backhoe.

sediments, bedrock, for working out rock-and-coal blocks and for individual coal seams' excavation.

The following scooping modes are used when working off the benches:

- working off the bench with the formation of the slope of the face by the horizontal layers from top to bottom;

- working off the bench with the formation of the slope of the face with inclined layers from top to bottom.

At present, the distribution of hydraulic backhoes made by well-known companies for some of coal open pits is shown in Table. I.

It is necessary to seek to the maximum use of the technical capabilities of the E hydraulic backhoes, to increase its productivity.

Analysis of the work of hydraulic excavators showed that their actual performance is only $26-58 \%$ of the passport. We can assume that such results are due to scientifically unjustified technological parameters, the combination of excavator-and-dump truck complexes and the quality of preparation (crushing) of rocks for excavation, and the lack of work experience.

TABLE I. AVAILABILITY OF HYDRAULIC BACKHOES ON SOME OPEN PITS OF KUZBASS

\begin{tabular}{|l|l|}
\hline \multicolumn{1}{|c|}{ Enterprise } & \multicolumn{1}{c|}{ Hydraulic backhoe } \\
\hline Section "Uregol” & $\begin{array}{l}\text { Terex RH40, Liebherr R984C, Caterpillar- } \\
\text { 5130, Liebherr R9250 }\end{array}$ \\
\hline $\begin{array}{l}\text { Section "Ananyin } \\
\text { West" }\end{array}$ & $\begin{array}{l}\text { Hyundai R450LC-7, Hitachi ZX-650 LCH, } \\
\text { Liebherr 984C Litronic, Liebherr R 974, } \\
\text { Liebherr R 9250, Komatsu PC400, Komatsu } \\
\text { PC400 LCH }\end{array}$ \\
\hline Section "Podgorny" & $\begin{array}{l}\text { Hitachi EX1200, Hitachi ZX870H, Hitachi } \\
\text { ZX450 }\end{array}$ \\
\hline Section "Stepanovsky" & $\begin{array}{l}\text { Hitachi EX-1200-5d,Hitachi EX-850,Hitachi } \\
\text { ZX- 450-3, Komatsu PC 1250-7, Liebherr } \\
\text { R984C, Liebherr R974C, Liebherr }\end{array}$ \\
& R954C,CAT 330C, Terex RH-40, Hitachi \\
& ZX-400LCH \\
\hline Section "Koksovy" & Cat-365, Cat-5110, Liebherr-984, Liebherr \\
& 994, Komatsu 2000. \\
\hline
\end{tabular}




\begin{tabular}{|l|l|}
\hline \multicolumn{1}{|c|}{ Enterprise } & \multicolumn{1}{c|}{ Hydraulic backhoe } \\
\hline Section "Salec" & Komatsu PC 1250, Liebherr R974SME, \\
& Liebherr R974SME, Liebherr R954C \\
\hline Section "Bungur & Hyundai 450 LC, Hitachi EX 1200, Komatsu \\
South" & PC- 1250, Komatsu PC-400, Daewoo 420LC, \\
& Hitachi ZX 650 LCH, Hitachi ZX 450, \\
& Liebherr R984C, Liebherr R974, Caterpillar \\
& 385, Volvo EC 460, Volvo EC 700. \\
\hline
\end{tabular}

Analysis of technological schemes for the application of hydraulic backhoes in sections of Kuzbass coal open pits showed that excavators mainly work with downward scooping with loading at or below the level of the excavator's position. Not always the optimum combination of an excavator with a dump truck according to the capacity of a dump truck body is maintained, depending on the length of transportation.

An analysis of the experience of using hydraulic excavators in open pit mining has shown that in order to increase the efficiency of their application it is necessary to conduct scientific research in the following areas:

- the substantiation of the face parameters depending on mining conditions and excavator digging mode;

- study of the dependence of the working cycle of the excavator on the mode of scooping of the loading scheme and the height of the face;

- the rationale combination of the excavator-and-dump truck complex;

- the study of the dependence of the excavator performance on the face parameters, the digging and slope complexity;

- the development of variants of technological schemes of work with the use of hydraulic excavators for various conditions of their application on the sections of Kuzbass open pits with an assessment of their effectiveness.

\section{THE SCHEME FOR DEFINING THE LAYER'S HEIGHT}

When mining coal, excavators are used with a small bucket capacity, usually not more than $5 \mathrm{~m} 3$. The technology of working out the seam on the "Stepanovsky" section varies depending on the dip angle of the seam. The dip angles vary from $26^{\circ}$ to $75^{\circ}$.

Let us consider the kinematic schemes of the operation of some hydraulic backhoes used on the "Stepanovsky" section for the following conditions (Fig. 2):

- the dip angles of coal seams lie from $25^{\circ}$ to $50^{\circ}$, as most often encountered in the sections of the Kuzbass;

- the height of the layer to be worked is 4,0-5,0 m;

We accept the value of the safety berm of $2.0 \mathrm{~m}[3,8,15]$.

The following units are indicated on the diagrams:

$R_{l}$ - the radius of the excavator drawing at a depth equal to the height of the layer (hl); m;

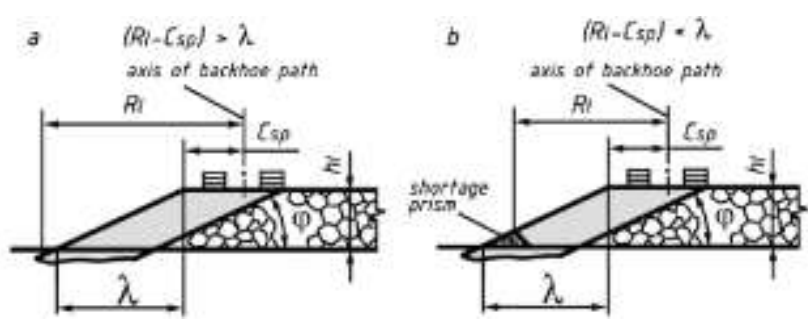

Fig. 2. Evaluation of the technical capability of the hydraulic backhoes on the prospecting: a) the complete excavation of the seam when the radius of excavating radius is equal to the height of the layer (hl); b) complete excavation of the formation if the excavating radius does not correspond to the layer's height (hl)

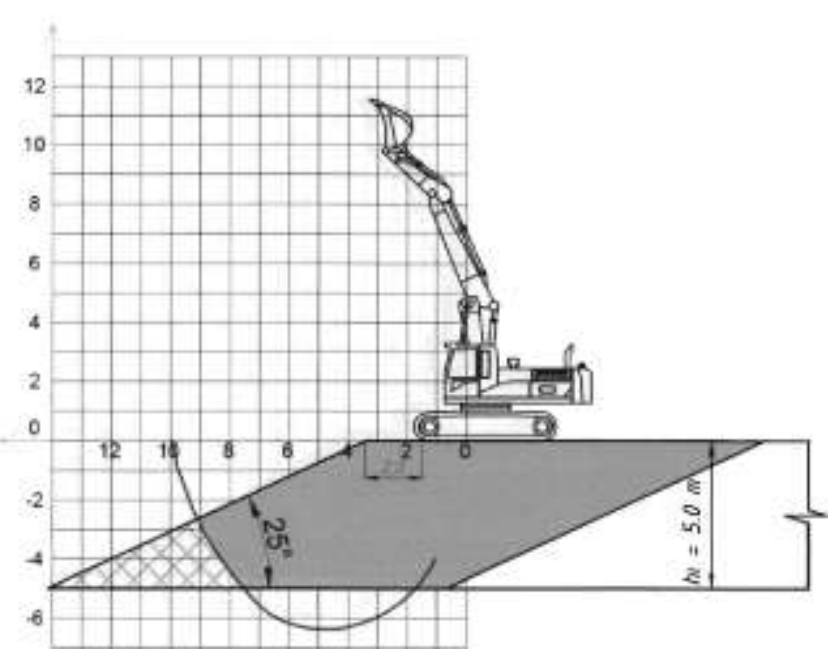

Fig. 3. Kinematic scheme of operation of hydraulic backhoe CAT 330S at a layer height $\mathrm{hl}=5.0 \mathrm{~m}$ and the dip angle of coal seam $\varphi=25^{\circ}$.

$C_{s p}$ - safe position of the excavator relative to the upper edge of the coal ledge, $\mathrm{m}$;

$\lambda$ - horizontal deposition of the slope of the coal bench, $\mathrm{m} ;$

$\varphi$ - angle of bedding, degrees

Fig. 3 shows a kinematic scheme of the hydraulic backhoe CAT $330 \mathrm{C}$ when $\mathrm{hl}=5.0 \mathrm{~m}$ and an dip angle of the seam $\varphi=25^{\circ}$. The excavator works with the downward digging, carries out the lifting of the rock mass in the bucket and can load it into transport vessels at or above the level of its standing. On Fig. 3, we see that a non-scooping prism is formed, with an area of $7.6 \mathrm{~m} 2$, preventing the installation of coal-carrying trucks for loading, and when it is developed with a bulldozer, the organization of work becomes more complicated, which leads to the loss of coal.

On Fig. 4, the kinematic scheme of operation of hydraulic backhoe CAT 330C is shown at a layer height $\mathrm{hl}=$ $5.0 \mathrm{~m}$, and the dip angle of the seam $\varphi=30^{\circ}$. The excavator works with the downward digging, carries out the lifting of the rock mass in the bucket and can load it into transport vessels at or above the level of its standing.

On Fig. 4 we see that a non-scooping prism is formed, with an area of $4.1 \mathrm{~m}^{2}$, preventing the installation of coal- 
carriers for loading, and when it is developed with

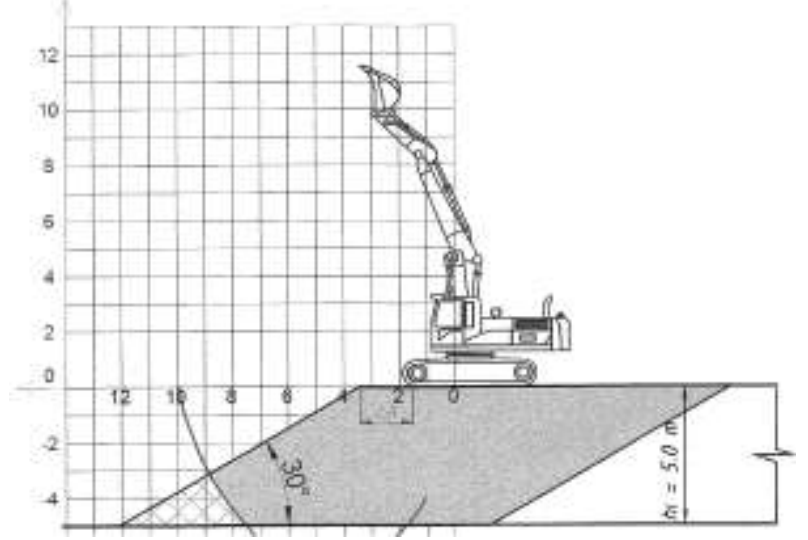

Fig. 4. The kinematic scheme of the operation of the hydraulic backhoe CAT $330 \mathrm{~S}$ at a layer height $\mathrm{hl}=5.0 \mathrm{~m}$ and the dip angle of coal seam $\varphi=$ $30^{\circ}$

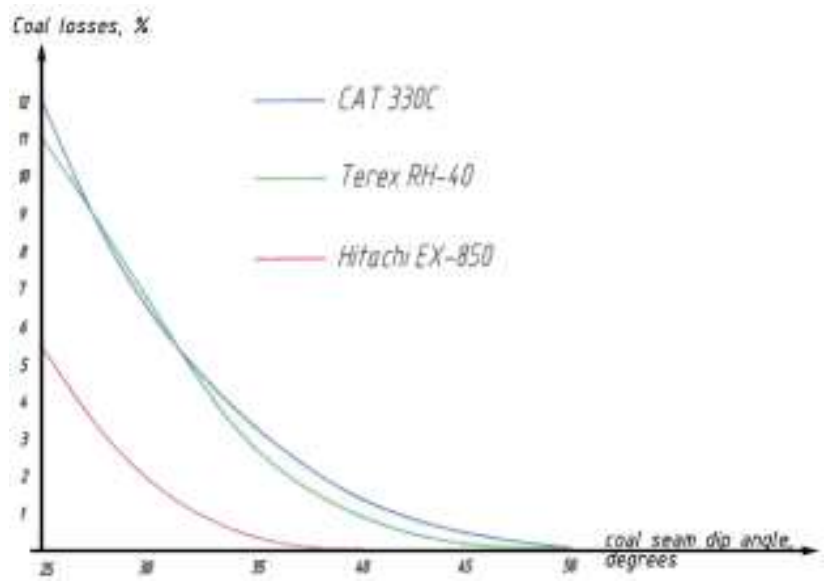

Fig. 5. Dependence of losses of coal on the dip angle of coal seam and the layer's height $\mathrm{hl}=5.0 \mathrm{~m}$, for various excavators.

a bulldozer, the organization of work is complicated and the loss of coal is increased.

Thus, with a layer height of $5.0 \mathrm{~m}$, a non-scooping prism is formed, so it is necessary to reduce the height of the layer. Dependence of losses of coal on the dip angle at a layer height $\mathrm{hl}$ and the use of various excavators is given in Fig. 56.

As we can see from the Fig. 5-6, the coal losses is reduced in 2-5 times when the excavated layer's height is decreased by $1 \mathrm{~m}$ only. It means that the future researches of excavated layer's height optimization are necessary.

\section{CONCLUSION}

When justifying the excavated layer height of the hydraulic backhoe for the conditions of the Kuzbass sections, we were guided by the following factors:

- equipment parameters;

- parameters of bedding: thickness, dip angle.

There are two options for working out coal seams:

Option 1 - the technology of working out coal seams is conducted according to the scheme of penetrating a cut trench and working out a coal seam with an angle of

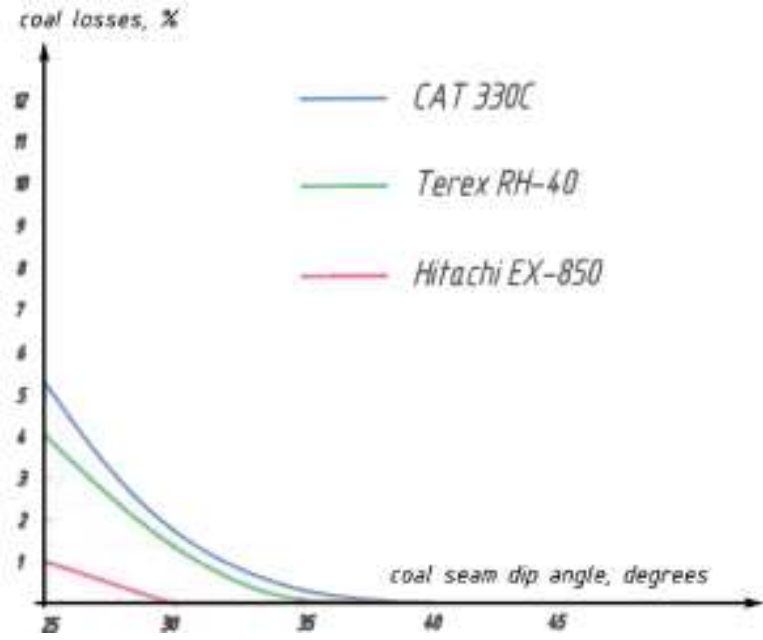

Fig. 6. Dependence of losses of coal on the dip angle of coal seam and the layer's height $\mathrm{hl}=4.0 \mathrm{~m}$, for various excavators.

incidence up to $40^{\circ}$ with two layers of hydraulic excavator Liebherr R954C type with a loading in a dump truck. This scheme has the following drawbacks:

- necessity of dividing the processed coal layer into 2 parts at a height of $2.5 \mathrm{~m}$ due to insufficient operating parameters of the equipment used;

- complicating the organization of the equipment operation due to the fact that a layer of overburden with a thickness $\mathrm{hl}=5.0 \mathrm{~m}$ is processed by one pass of the excavator, and the coal seam is to be further divided, which leads either to the use of two excavators or to an increase in the working time of the formation.

Option 2 - the technology of working out coal seams is conducted with penetration of a cut trench and mining a coal seam with dip angle up to $40^{\circ}$ with three layers by Liebherr $\mathrm{R} 954 \mathrm{C}$ backhoe with loading into the dump truck. It is more expedient to use the scheme of the second variant, which allows eliminating coal losses.

The obtained results can be used in the design of mining operations for the Kuzbass sections that develop coal seams of any capacity in the calculated range of dip angles of 25$55^{\circ}$.

\section{REFERENCES}

[1] A. Krechetov, A. Khoreshok, and V. Blumenstein, "Innovative Competencies of Mining engineers in Transition to the Sustainable Development," E3S Web of Conferences, vol. 21, p. 00001, November 2017. DOI: https://doi.org/10.1051/e3sconf/20172100001

[2] V.A. Kovalev, A.A. Khoreshok, and O.I. Litvin, "The Role of Innovative Technologies in Solving Kuzbass Coal Industry GeoEcological Problems," Proceedings of the 8th Russian-Chinese Symposium Coal in the 21st Century: Mining, Processing, Safety, vol.92, pp. 287-290, 2016.

[3] J. Kretschmann, A.B. Efremenkov, and A.A. Khoreshok, "From Mining to Post-Mining: The Sustainable Development Strategy of the German Hard Coal Mining Industry," IOP Conference Series - Earth and Environmental Science, vol. 50, p. 012024, 2017.

[4] M. Cehlar and I. Cehlarova, "Cut winnings methods of an open-pit mine development," Acta Montanistica Slovaca, vol. 12 (3), pp. 174$181,2007$.

[5] M. Cehlar, K. Teplicka, and S. Szabo, "Possibility of new mining project extracting in conditions of crisis," Acta Montanistica Slovaca, vol. 14 (4), pp. 314-322, 2009. 
[6] M. Cehlar, I. Cehlarova, and J. Szaboova, "Economic variables of the mineral project like the factors affecting cash flow," Acta Montanistica Slovaca, vol. 12 (3), pp. 133-139, 2007.

[7] O. Golbasi and N. Demirel, "Optimisation of dragline inspection intervals with time-counter algorithm," International Journal of Mining Reclamation and Environment, vol. 31(6), pp. 412-425, 2017.

[8] N. Demirel and C. Karpuz, "Surface Coal Production Methods and Equipments," in Coal Production and Processing Technology, 2016, pp. 149-160.

[9] Intelligent service of reducers of mining machines / B.L. Gerike, V.I Klishin, P.B. Gerike, A.A. Mokrushev // Journal of Mining and Geotechnical Engineering. - 2018. - №1 - pp. 19-34. DOI: 10.26730/2618-7434-2018-1-19-34

[10] V. Kolesnikov, O. Litvin, J. Janočko, and A. Efremenkov, "Using of Wide Stopes in Coalless Zones Mined by Shovels and Backhoes," E3S Web Conf., vol. 21, p. 01031, November 2017. DOI: https://doi.org/10.1051/e3sconf/20172101031

[11] O. Golbasi and N. Demirel, "Investigation of stress in an earthmover bucket using finite element analysis: a generic model for draglines,"
The Journal of The Southern African Institute of Mining and Metallurgy, vol. 115, pp. 623-628, 2015

[12] Martyanov V.L. Evaluation of the working out difficulty on quarry fields of Kuzbass coal deposits / V.L. Martyanov // Journal of Mining and Geotechnical Engineering. - 2018. - №1. - pp. 35-41. DOI: $10.26730 / 2618-7434-2018-1-35-41$

[13] Prospects of disk tools using on executive bodies of mining machines / A.A. Khoreshok, L.E. Mametyev, A.M. Tsekhin, A.Yu. Borisov // Journal of Mining and Geotechnical Engineering. - 2018. - №1. - pp. 64-80. DOI: $10.26730 / 2618-7434-2018-1-64-80$

[14] Katsubin A.V. Systematization of the technological schemes of excavator faces at the central Kuzbass open pit mines / A.V. Katsubin, E.V. Makridin // Journal of Mining and Geotechnical Engineering. 2018. - №1 . - pp. 81-88. DOI: 10.26730/2618-7434-2018-1-81-88

[15] M. Haftu, B. Konka, K. Woldearga, and A. Abay, "Slope Stability Assessment and Underground Mine Design Analysis of AchiboSombo Underground Conventional Coal Mine, Southwest Ethiopia," E3S Web Conf., vol. 15, p. 01004, April 2017. DOI: https://doi.org/10.1051/e3sconf/20171501004 